\title{
地すべり地における水位変動のモデル解析

\author{
Model Analysis of Ground Water Level Fluctuation in Landslide Areas
}

\section{榎 田 充 哉* \\ Mitsuya ENOKIDA}

\begin{abstract}
We don't understand enough communication mechanism of pore water pressure on slip surface.

In the present paper, we shall try to make a few new theoretical models of complicated mechanism of ground water level fluctuation in landslide areas.

By the modeling of mechanism, we shall be able to catch both timelags between rainfall and ground water level fluctuation and the fluctuation size is a match for rainfall.

We design two theoretical models, tank model and $\Psi$ function model. After that, we explain theory of each model. And we set standards of modeles for valuation. Therefore we provided two models that is effective to understand properties of ground water level fluctuation in landslide areas.

キーワード: 降雨, 地すべり, 水位低下, 地下水
\end{abstract}

\section{1.はじめに}

地すべり滑動にすべり面の間隙水圧が大きく関わって いることは周知の事実である。間隙水圧がある限界を超 えることによって地すべりは滑動を始める。しかし，地 すべり地の地下水の動きは複雑で, すべり面付近の地下 水帯へとたどりつくまでに幾つもの帯水層または水脈が 関与しているとおもわれるが1), その機構については十 分に解明されていない。

本研究ではその複雑な水位変動機構の新しいモデル化 を試みた。

水位変動をモデル化することにより降雨に対する水位 変動の大きさと時間差を把握することができる。水位変 動の大きさを知ることで, ある降雨量に対する地すべり 滑動の有無を知ることができ, 時間差を知ることで, 降 雨の後の地すべり滑動の発生時間を予知することに役立 つ。また，モデル定数の值によって排水計画を立て，モ デル定数の経年変化によって排水工法の効果を判定する ことができる。将来予想される豪雨に対する地すべりの 安定度を検討することも可能となるなど, モデル化によ る利点は大きい。

本研究では二つのモデルを用いた。

一つのモデルは流出解析によく用いられるタンクモデ ルを多少改良した従来型のモデルで,もう一つは $\Psi$ 関数 モデルと名付けた今回新たに提案するモデルである。こ

* 国土防災技術㑣
れら二つのモデルの理論的意味を説明するとともに，い くつかの地すべり地においての解析結果と観測デー夕を 比較検討することによって，地すべり地での水位変動モ デルとしてのニつのモデルの有効性の検証を行ったので その結果を報告する。

今回, 長崎県平山地区, 長崎県牧の地地区, 岐阜県石 原地区の三つの地すべり地の観測デー夕を用いた。

地すべり地での水位変動特性に関する報告はこれまで にも数多くなされているが, 過去の報告の中には, 帯水 層が複数あるにもかかわらず全長ストレーナ加工の観測 孔のデー夕を用いたものや，測定時間間隔が長いものな ぞ, 水位の測定方法に疑問を感じるものも多くみられた。

今回用いた水位デー夕はそのほとんどがすべり面付近 の地下水帯部分のみをストレーナ加工し，その上下に遮 水処理を施した観測孔のデータであり, 測定間隔が 5 分, 記録間隔が 20 分〜 1 時間と非常に高品位で, 水位変動を 詳細に捉えたものである。

\section{2. 地すべり地の概要}

ここで取り上げた三つの地すべり地の概要を以下に述 ベる。

平山地すべりは長崎県松浦郡に位置し, 標高 $270 \mathrm{~m}$ の 愛宕山の山腹斜面と山麓の棚田地帯を含む面積約 64 ha の地すべりである。地質は第三紀中新世の佐世保層群世 知原層とこの上を不整合に覆う八の久保砂磁層および松 浦玄武岩類から構成される。当地すべり地の世知原層は 
砂岩, 頁岩の互層からなり，2～3 枚の薄い炭層が㣣在す る。地すべりはこの夾炭層をすべり面とした典型的な岩 盤すべりである。すべり面の地下水は調査結果より有圧 地下水であることが確認されている。解析に用いた観測 井 No. 1 は地すべり末端部に位置する。

石原地すべりは岐皁県大野郡に位置し，地質は西南日 本内帯の美濃帯に属し，主にジュラ紀の砂岩，頁岩より 構成される。地すべりは面積約 1～2 ha の四つのブロッ クからなり, 斜面傾斜 $40^{\circ}$ 前後の急峻な斜面に発生して いる。解析に用いた観測孔 $\mathrm{CH} 8$ は地すべりブロック IV の中腹部に, 観測孔 CH 18 は地すべりブロック I の末端 部付近に位置する。

牧の地地すべりは長崎県佐世保市の北側にあり，五蔵 岳から妙観寺峠にいたる稜線の南端部に位置する。地す ベり全体の面積は約 19 ha で, 地質は新第三紀佐世保層 群世知原層に属し，基岩は細～粗粒砂岩，頁岩，砂質頁 岩から構成されている。砂質頁岩の間には層厚 $2.0 \sim 3.5$ $\mathrm{m}$ の石炭, 凝灰岩, 凝灰質砂岩の細互層を㣣在してい る。

解析対象のボーリング孔は基岩である砂質頁岩の上に 帯水層である砂碟層が，その上を砂岩と崩積土が覆い, 地下水検層結果からもすべり面付近の地下水は被圧地下 水であることが確認されている。解析に用いた観測孔 $\mathrm{CH} 10$ は C ブロックの冠頭部付近に位置する。

\section{3. 水位変動モデル}

図 -1 は水位変動と地すべり移動量の関係をみたもの である2。間隙水圧がある值を超えると地すべりの移動 量が大きくなっている。このように水位変動と地すべり の移動は密接に関わっており，水位変動の大きさと時期 が地すべり滑動に大きな影響を与えている。

地すべりの地下水位変動をモデル化するうえで，その モデルにまず求められるものは

(1)水位変動の大きさを予測できるか。 (2)時間差を予測できるか。

である。次に求められるものが

(3)理論的な裏付けがあるか。

(4)モデル定数の決定が容易であるか。

(5)計算方法が簡単・明瞭であるか。

(6)モデル定数が水位変動の特性を言い表す特性値とな り得るか。

(7)一つの解析の所要時間が短時間であるか。

であると考える。

「観測水位を相関よく再現する解析水位」というよう な表現をするが，地すべり地での水位変動モデルは単に 相関がよいだけでは失格であり，刻々と変化する降雨 デー夕を基に，その後何時にどの高さまで水位が上昇す

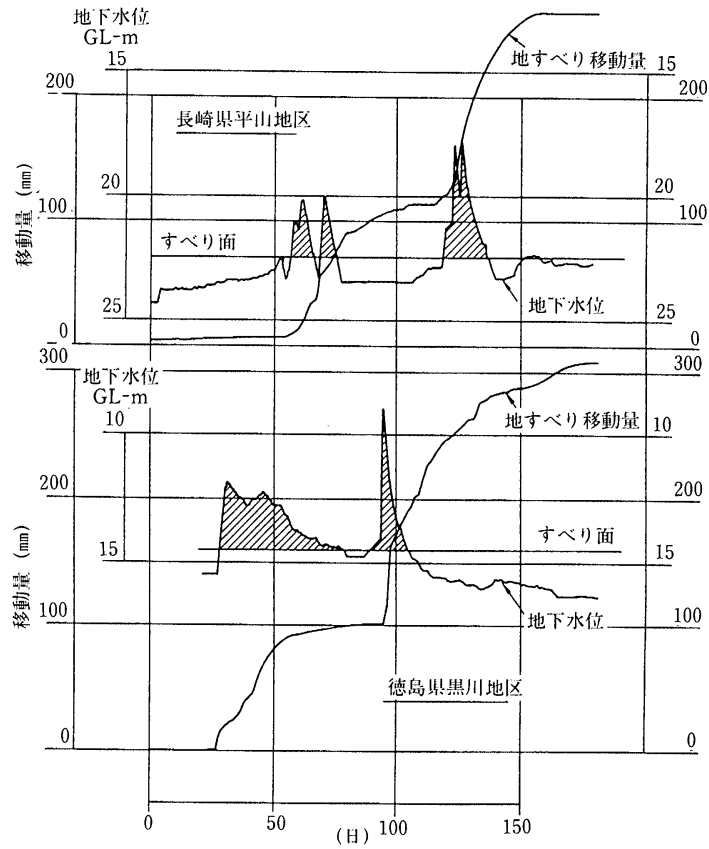

図一1 地下水位（関隙水圧）と地すべり移動 (地すべり工学より)

るかを予測できなければならない。その意味では単に相 関だけを合わせるモデルや，一つ一つの解析に数時間も 要したり，大型コンピュータでなければ処理できないモ デルは実用的でない。

今回検討を行った二つのモデルは, 流出解析でよく用 いられるタンクモデルを基本とするモデルと, 本研究で 新たに提案する $\Psi$ 関数モデルである。それぞれの基本的 な考え方と理論を以下に示す。

\section{1 地すべり地の地下水の特徵}

地すべり地での地下水の動きは複雑であるが，これま での観測結果からわかったいくつかの特徵と, 地すべり 地の地下水に対する基本的な考え方について整理してみ る。これらは水位変動機構をモデル化する上での基本的 な概念である。

\section{1 .1 自由地下水と被圧地下水}

図一2に山地における地下水帯の模式図を示す1。 地下水は地下水を包蔵しているものが地層であるか断 裂（断層・裂か・節理など）であるかによって，それぞ れ地層水（stratum water）と裂か水（fissure water） に定義される。また, 地層水は自由地下水と被圧地下水 に，裂か水は不圧水と有圧水とに分けることができる。 地すべり地ではこれらの地下水帯が混在しているもの と思われる。また，図－2にみるように地すべり地の被圧 地下水帯は平野における完全な被圧地下水帯と違い, 端 部の一部が自由地下水と連続しているなどの疑似の被圧 地下水帯でることが多いと思われる。 


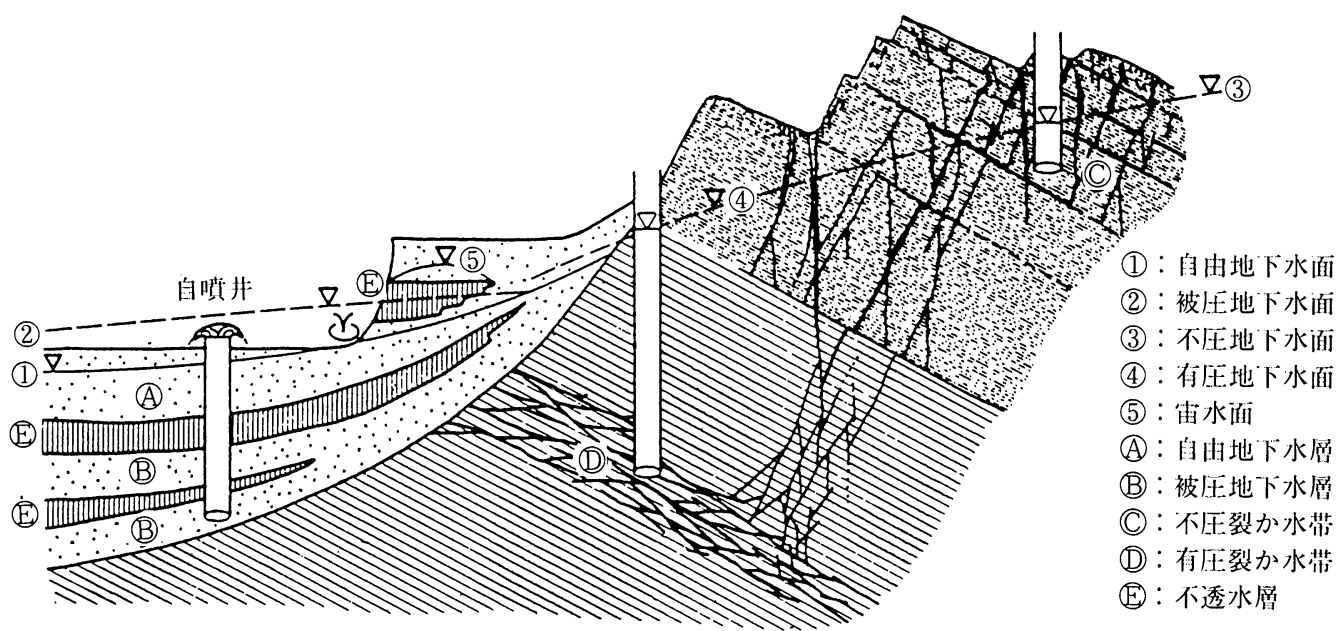

图ー2 斜面の水文地質構造（地すべり工学より）

本研究では地下水を自由地下水および不圧水と被圧地 下水および有圧水の二つのグループに分けて取り扱う。 以後, 自由地下水帯という表現には不圧水帯も含み, 被 圧地下水帯という表現には有圧水帯も含むものとする。

地すべり地におけるこの二つの地下水の基本的な性質 をモデル解析の立場から考えてみる。

自由地下水帯の水頭は水の量そのものを反映したもの である。水の星と地下水帯の有効な空隙率によってその 高さが決まる。「水頭の変化 $\rightarrow$ 水の量の変化」なのであ る。入力項である降雨量または融雪水量と圧力水頭は 「量」の面である均衡がとれていなければならない。

それに対し, 被圧地下水または有圧水の圧力水頭は水 の是を直接反映していない。貯留係数 $\mathrm{s}$ で比較すると,自 由地下水帯の $\mathrm{s}$ は有効間隙率 (一般に $5 \times 10^{-2} \sim 3 \times 10^{-1}$ ) にほほ等しいのに対し, 被圧地下水帯では一般に $5 \times$ $10^{-5} \sim 5 \times 10^{-3}$ と 100 倍程度の違いがある ${ }^{3)}$ 。つまり，自 由地下水帯と同じ水頭変化量に対する水の量の変化は 100 分の 1 程度となる。

地すべり地における疑似の被圧地下水带では地層の圧 縮率は考慮しないものとする。

被圧地下水帯または有圧水帯の圧力水頭が変化すると 帯水層または水脈内の水の密度が変化する。以下の二つ のモデル解析では地下水を非圧縮性と仮定しているが, 水は $0-500$ 気圧の平均で 1 気圧当たり $4.5 \times 10^{-3} \%$ 程 度の体積の圧縮性を持っている4)。密度がわずか $4.5 \times$ $10^{-3} \%$ 変化するだけで 1 気圧, 約 $10 \mathrm{~m}$ の水頭変化がおこ る。

このように被圧地下水帯または有圧水帯の水頭変化は 外部からの圧力に大きく影響されるのであり, 降雨量の ような水の望には直接には影響されない。解析の目的に よっては圧力水頭の変化と水の些の収支を無視すること

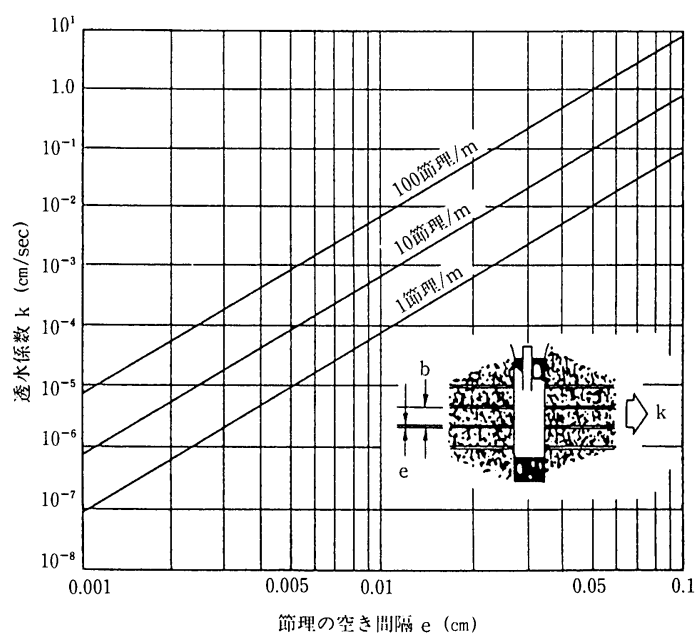

図ー3 岩盤内平滑な平行節理系構造と透水係数 (Louis)による

ができる。

\section{1 .2 すべり面付近の地下水帯}

すべり面は一般に粘土分を多く含んだ土で構成されて おり，透水性は極めて低い。すべり面に揚圧力を与える 地下水帯はすべり面周辺の龟裂帯または透水性の良い地 層であると考えられる。

これまでの全国の地すべり地での検層結果などからみ ると, この地下水帯は上部に不透水層または難透水層を もつ疑似の被圧地下水带や有圧水帯であることが多く, 完全な自由地下水帯である場合は希である。

図-3 は龟裂の大きさと透水係数の関係を示した資料 であるが5)，わずかなすきま幅の龟裂でも砂質土程度の 透水係数を持つことがわかる。

\section{1 .3 水位変動パターン}

地すべり地での水位変動には大きく二つのパターンが 
ある。パターン 1 は個々の降雨に対し敏感に反応し, 水 位低下も比較的急激な変動。このパターンの場合, 降雨 のピークと水位のピークとの時間的なずれが通常 $1 \sim 2$ 日程度である。パターン 2 は個々の降雨にはあまり反応 せず全体として大きく変動するもので, 水位低下が緩慢 で，ピークの時間差も数日から数力月と大きい。

またパターン 2 の中には大きな水位上昇が始まる時間 と大きな降雨との時間差があまりない夕イプと時間差が 数日以上あるタイプがある。

ここで遅延時間について整理してみる。

本研究では遅延時間を以下の二つに区別している。

(1)降雨が水位上昇に影響を与え始めるまでの時間差

(2)降雨と水位のピーク時との時間差 $\left(\mathrm{T}_{\mathrm{p}}\right)$

以後, $T_{0}$ を初期遅延時間, $T_{p}$ をピーク遅延時間と呼ん で区別する。

地すべりの安定上, より問題となるのは(2)のピーク遅 延時間 $\mathrm{T}_{\mathrm{p}}$ である。

\section{2 タンクモデル}

図一 4 に今回用いたタンクモデルの模式図を示す。

各タンクは一つの浸透孔と二つの越流孔をもち, 一方 の越流孔の流量が次のタンクへ流入する。浸透孔の流量 を次のタンクの入力とした場合は, 極めて小量の降雨も タンクの状態に関係なくすべて次のタンクの水位に影響 することになり，実際の現象にあわない。

タンクは全部で 5 段用いる。最上部タンクが地表付近
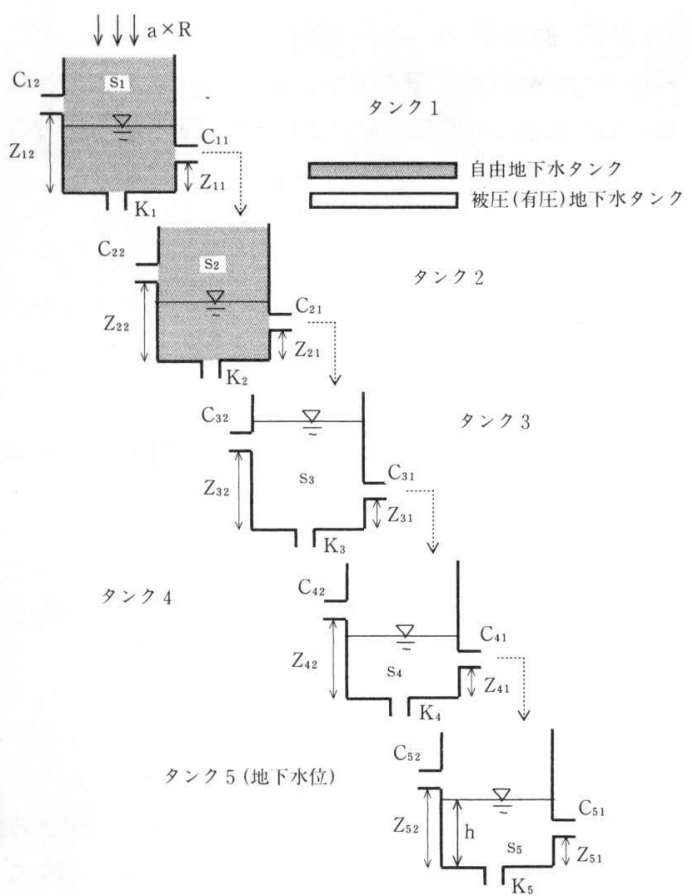

図-4 タンクモデルの模式図
の土壌を代表し， 5 段目のタンクがすべり面周辺の地下 水帯を， 2 段目から 4 段目のタンクが地下水流入経路の いくつかの地下水帯を表現している。流出解析では 3 段 のタンクモデルがよく用いられるが, 3 段では初期遅延 時間 $\mathrm{T}_{0}$ をうまく再現できない。本論文に用いた観測水 位は初期遅延時間がほとんどないものばかりであるが, 地下水位変動には水位上昇の開始時間が降雨から数日遅 れるものもあり, タンク数を増やすことによって初期遅 延時間 $\mathrm{T}_{0}$ が表現可能になる。しかし, タンク数をあまり 増やしすぎると $\mathrm{T}_{0}$ の少ない水位変動を表現することが むずかしくなる。1段から 10 段までの解析結果を比較検 討した結果，5段程度が地すべり地での最高でも数日程 度の初期遅延時間は再現可能であり, 妥当であると判断 した。

タンクを 3 段にして, 初期遅延時間 $\mathrm{T}_{0}$ を一つの係数 とするモデルも考えられるが，ここでは 5 段のタンクモ デルを用いて解析を行った。

一般の地下水 2 次元シミュレーションと違いタンクモ デルではタンク間の圧力の相互作用を考慮しない。その ために計算が非常に単純であるという利点がある。

一般的な流出解析の夕ンクモデルと本モデルの大きな 違いは, 流出解析では最終的に水の流出量 $\mathrm{Q}$ を必要とす るが, 地下水位変動解析ではタンク内の水頭の高さが必 要となる点である。各タンク (地下水帯) にはそれぞれ の貯留係数 $\mathrm{s}$ があり, 各タンクの流入量にはそのタンク の貯留係数が含まれなければならない。

単純な 2 段の夕ンクの場合を例に基本的な地下水流動 を考えてみる。

1 段目から 2 段目への流入量 $Q_{1}$ は 1 段目の越流係数 $\mathrm{C}_{1}$ と水位 $\mathrm{h}_{1}$ より,

$$
\mathrm{Q}_{1}=\mathrm{C}_{1} \cdot \mathrm{h}_{1}
$$

と表現できる。ここに, 越流係数 $\mathrm{C}_{1}$ は夕ンク間の透水係 数 $\mathrm{k}$, 経路の断面積 $\mathrm{A}$, 経路の長さ $\mathrm{L} よ り$,

$$
\mathrm{C}_{1} \fallingdotseq \mathrm{k} \cdot \mathrm{A} \cdot \Delta \mathrm{t} / \mathrm{L}
$$

で与えられる。

各タンクの底面積を単位面積とすると, $\mathrm{Q}_{1}$ によるタン ク 1 の水位変化 $\Delta \mathrm{h}_{1}$ は, タンク 1 の貯留係数 $\mathrm{s}_{1}$ より,

$$
-\Delta \mathrm{h}_{1}=\mathrm{Q}_{1} / \mathrm{s}_{1}=\mathrm{C}_{1} \cdot \mathrm{h}_{1} / \mathrm{s}_{1}
$$

となる。また, $\mathrm{Q}_{1}$ の流入によるタンク 2 の水位変化 $\Delta \mathrm{h}_{2}$ は, タンク 2 の貯留係数 $\mathrm{S}_{2}$ を用いて,

$\Delta \mathrm{h}_{2}=\mathrm{Q}_{1} / \mathrm{s}_{2}$ となる。

ここで, 水位変化のみに注目し, $\mathrm{C}_{1} / \mathrm{s}_{1}$ を改めて係数 $\mathrm{C}_{1}{ }^{\prime}$ で表現することにより, タンク間の地下水量の収支を 水頭 h の収支として考えることができる。

つまり, タンク 1 の水位変化 $\Delta \mathrm{h}_{1}$ は

$$
-\Delta \mathrm{h}_{1}=\mathrm{C}_{1}{ }^{\prime} \cdot \mathrm{h}_{1}
$$


となり，それによるタンク 2 の水位変化 $\Delta \mathrm{h}_{2}$ は

$\Delta \mathrm{h}_{2}=-\Delta \mathrm{h}_{1} \cdot \mathrm{s}_{1} / \mathrm{s}_{2}$

となる。 $\mathrm{s}_{2} / \mathrm{s}_{1}$ を改めて $\mathrm{s}_{2}{ }^{\prime}$ と表現することで,

$\Delta \mathrm{h}_{2}=-\Delta \mathrm{h}_{1} / \mathrm{s}_{2}^{\prime}$

となる。

つまり, 水位変化のみに注目し, 各タンクの入力項に その貯留係数 $\mathrm{s}^{\prime}$ を考慮することにより, タンク内での水 位収支を従来のタンクモデルの収支計算と同様に解析可 能である。ただし, 各越流孔や浸透孔から排出されるも のは流量 $\mathrm{Q}$ ではなく, 水頭変化量 $\Delta \mathrm{h}$ となる。

当然, 最上部タンクの入力項である降雨量にも最上部 タンクの貯留係数が加味される。また，連続するタンク の貯留係数がほぼ等しい場合は, $\mathrm{s}^{\prime} \fallingdotseq 1$ となり, 計算はよ り簡単になる。

流量 Q に注目すると, 最下端の地下水夕ンクを除く他 のタンクの貯留係数の効果は相殺される。つまり, 4 段目 までのタンクの水収支を通常の流出解析の収支計算で行 い, 最終タンクの入力項にのみ, そのタンクの貯留係数 を加味する解析方法も可能である。

また, 流出解析では流域内の全降雨量と全流出量や蒸 発散量等の収支の均衡がとれていなければならないが， 地下水は流域内を均一に流れているのでなく透水性の良 い地層や水脈を片寄りをもって流れていると思われ， 個々の地点での地下水の変動解析モデルである本モデル では流域内での降雨の集水の度合いを集水係数 a とし て考慮する。

\section{$3.3 \Psi$ 関数モデル}

図-5に $\Psi$ 関数モデルの模式図を示す。 モデルの基本的な考え方を説明する。

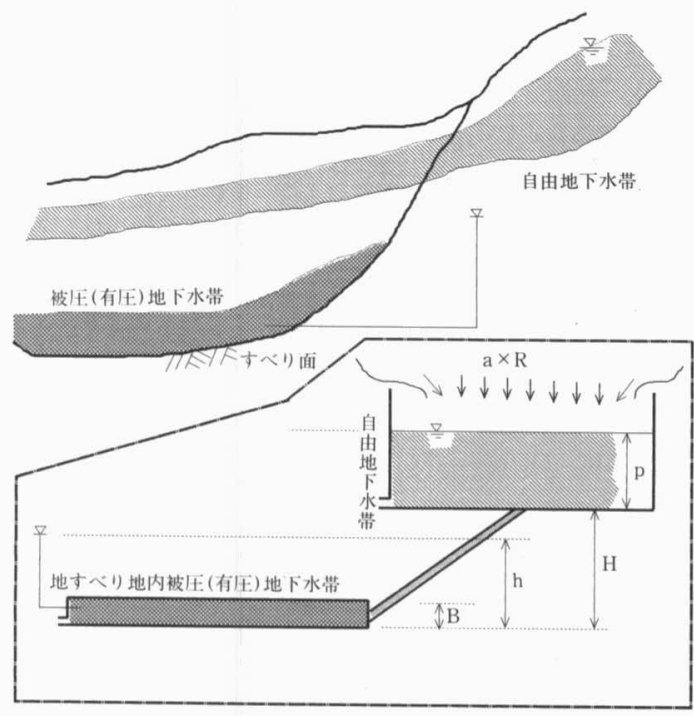

図-5 $\quad \Psi$ 関数モデルの模式図
地すべり地を含む流域内に降った雨は必ず最初に自由 地下水帯または不圧水帯に供給される。流域内の自由地 下水帯は地すべり地およびその周辺の自由地下水帯と何 らかの連続性を持っている。

地すべり地周辺と流域内の降雨の一部はやがて地すべ り地周辺の自由地下水帯に供給され, その自由地下水帯 の圧力が龟裂や地層を介してすべり面付近の被圧地下水 带または有圧水帯に伝わると仮定する。

$\Psi$ 関数モデルはこのように雨水を貯留する自由地下 水帯 (不圧水帯) とすべり面付近の被圧地下水帯（有圧 水帯）からなる単純な 2 層構造のモデルである。

地下水量の収支は降雨の浸透量と自由地下水帯 (不圧 水帯）の水位変化でほほ均衡がとれており, 被圧地下水 帯 (有圧水帯) の水頭変化による地下水量の消費は無視 できるものとする。

以上の仮定により，まず地すべり地周辺の自由地下水 帯の水位 $\mathrm{p}$ の変化を考える。降雨の入力がない場合の自 由地下水帯の水位低下は低下速度が水位に比例するとし て，以下の式で表現される。

$-\frac{\mathrm{dp}}{\mathrm{dt}}=\rho \mathrm{p} \cdots \cdots \cdots \cdots \cdots \cdots \cdots \cdots \cdots \cdots \cdots \cdots \cdots \cdots \cdots(\because$ : 比例定数 $)$

$\mathrm{t}=0$ における水位を $\mathrm{p}_{0}$ とすると

$\mathrm{p}=\mathrm{p}_{0} \mathrm{e}^{-\rho \mathrm{t}}$

となる。

時刻 $\mathrm{t}_{0}$ の水位 $\mathrm{p}_{0}$ を規準にその後の水位変動を考えて みる。

降雨がこの自由地下水帯に到達するまでの遅延時間を $\mathrm{T}_{0}$ とし, 時刻 $\mathrm{t}_{0} \sim \mathrm{t}_{0}+\Delta \mathrm{t}$ の間に流入する時刻 $\mathrm{t}_{0}-\mathrm{T}_{0}$ $\sim \mathrm{t}_{0}-\mathrm{T}_{0}+\Delta \mathrm{t}$ 間の雨量を $\mathrm{R}_{-\mathrm{T} 0}$, 流域内の集水係数を $\mathrm{a}$, 自由地下水帯の貯留係数を $\mathrm{s}$ とすると, 時刻 $\mathrm{t}_{0}+\Delta \mathrm{t}$ での 水位 $\mathrm{p}_{1}$ は

$$
\mathrm{p}_{1}=\mathrm{p}_{0} \times \mathrm{e}^{-\rho \Delta \mathrm{t}}+\mathrm{a} \times \mathrm{R}_{-\mathrm{T} 0} / \mathrm{s}
$$

次の $\Delta \mathrm{t}$ 後の水位 $\mathrm{p}_{2}$ は

$$
\mathrm{p}_{2}=\mathrm{p}_{1} \times \mathrm{e}^{-\rho \Delta \mathrm{t}}+\mathrm{a} \times \mathrm{R}_{-\mathrm{T} 0}+\Delta_{\mathrm{t}} / \mathrm{s}
$$

となる。これを繰り返すと $\mathrm{k} \times \Delta \mathrm{t}$ 後の水位 $\mathrm{p}_{\mathrm{k}}$ は

$$
\mathrm{p}_{\mathrm{k}}=\mathrm{p}_{\mathrm{k}-1} \times \mathrm{e}^{-\rho \Delta \mathrm{t}}+\mathrm{a} \times \mathrm{R}_{-\mathrm{T} 0}+\Delta_{\mathrm{t} \cdot(\mathrm{k}-1)} / \mathrm{s}
$$

よって任意の時刻の水位 $\mathrm{p}$ はその時刻を規準にした過 去の履歴によって次のように表現できる。

$$
\begin{gathered}
\mathrm{p}=\varepsilon \sum_{\mathrm{n}=1}^{\infty} \alpha^{\mathrm{n}-1} \cdot \mathrm{R}_{-(\mathrm{T} 0+\Delta \mathrm{t} \cdot(\mathrm{n}-1))} \\
\text { ここに, } \alpha=\mathrm{e}^{-\rho \Delta \mathrm{t}} \\
\varepsilon=\mathrm{a} / \mathrm{s}
\end{gathered}
$$

$\Delta \mathrm{t}$ を単位時間（1 時間）にとることで式 (1) は簡素化し, $\alpha$ が一つの定数となる。

つぎに, 目的とする被圧地下水带の水頭変化を考える。 被圧地下水帯でも水頭の低下速度は水頭高に比例する と考え，比例定数を $\eta$ とすると 


$$
-\mathrm{dh}=\eta \cdot \mathrm{h} \cdot \mathrm{dt}
$$

となる。

圧力水頭 $\mathrm{h}$ は通常すべり面からの水頭高をとるが, 圧 力水頭が帯水層厚 Bより高い場合と低い場合では比例 定数が異なることが考えられる。比例定数 $\eta$ は前者の比 例定数であり, 便宜的に, 比例する 0 点の高さ $\mathrm{B}_{0}$ を設定 し，上記の式を

$$
\begin{aligned}
& -\mathrm{dh}=\eta \cdot\left(\mathrm{h}-\mathrm{B}_{0}\right) \cdot \mathrm{dt} \\
& \text { ここに, } 0 \leqq \mathrm{~B}_{0} \leqq \mathrm{~B}
\end{aligned}
$$

と変更する。

ある時刻の水頭高を $h_{0}$ とすると微少時間 $\Delta t$ 後の水 頭高 $h_{1}$ は近似的に

$$
\mathrm{h}_{1}=\mathrm{h}_{0}-\eta\left(\mathrm{h}_{0}-\mathrm{B}_{0}\right) \Delta \mathrm{t}+\Psi
$$

と表現できる。ここに， $\Psi$ は $\Delta \mathrm{t}$ 間に自由地下水帯から供 給された圧力である。

$\Psi$ の值は自由地下水帯と被圧地下水帯の圧力差に比 例し，次式で表現できる。

$$
\Psi=\gamma(\mathrm{p}+\mathrm{H}-\mathrm{h})
$$

ここに, $\mathrm{H}$ : 自由地下水帯と被圧地下水帯の標高差 $\gamma:$ 比例定数

比例定数 $\gamma$ はダルシーの法則から, 流入経路の透水係 数 $\mathrm{k}$ と断面積 $\mathrm{A}$, 経路の長さ $\mathrm{L}$, 被圧地下水帯の広がり $\mathrm{S}_{\mathrm{a}}$, 貯留係数 $\mathrm{s}$ などによって決定され, おおよそ次式で表 現される。

$$
\gamma=\mathrm{k} \cdot \mathrm{A} \cdot \Delta \mathrm{t} /\left(\mathrm{L} \cdot \mathrm{S}_{\mathrm{a}} \cdot \mathrm{s}\right) \cdot
$$

$\gamma$ も式(1)の $\alpha$ 同様, $\Delta \mathrm{t}$ を単位時間 (1 時間)にとるこ とによって定数となる。

式(1)，(3), (4)の定数 $\alpha, \varepsilon, \gamma, \mathrm{H}$ を推定し, 式(2)の比 例定数 $\eta, \mathrm{B}_{0}$, 初期水頭高 $\mathrm{h}_{0}$ と式 (1) の遅延時間 $\mathrm{T}_{0}$ を与 えることにより,式 (2) を用いて被圧地下水帯の水頭変化 を算出することができる。

被圧地下水帯の水頭上昇に重要な役割を果たす, 式 (3) の $\Psi$ を $\Psi$ 関数と名付け，このモデルを $\Psi$ 関数モデルと よぶ。式 (2) と式 (3) が $\Psi$ 関数モデルの解析式である。

前項のタンクモデルの未知数が最大 31 個であるのに 対し， $\Psi$ 関数モデルでは 7 個であり, 試行錯誤による定 数の決定が容易である。

ここで, 各定数の名称を以下のように定める。

(1) $\alpha$ : 先行雨量効果残留率

(2) $\varepsilon$ : 流域係数

(3) $\gamma$ : 浸透係数 $\left[\mathrm{m}^{-2} / \mathrm{hr}\right]$

(4) $\eta$ : 水位低下係数 $[\mathrm{m} / \mathrm{hr} / \mathrm{m}]$

(5) $\mathrm{H}$ : 帯水層標高差 $[\mathrm{m}]$

(6) $T_{0}$ : 初期遅延時間 [hr]

(7) $\mathrm{B}_{0}$ : 水位基準点

流域係数 $\varepsilon$ と浸透係数 $\gamma$ の值を推定してみる。

自由地下水帯の貯留係数 $\mathrm{s}$ が平均で 0.1 程度であると
すると, $\varepsilon$ は少なくとも数十以上となる。集水係数 a を考 慮すると経験上, $\varepsilon$ は $10^{2} \sim 10^{4}$ のオーダーとなる。 $\gamma$ の 值は, 透水係数 $\mathrm{k}$ を $10^{-2} \mathrm{~m} / \mathrm{hr}$ 程度, 貯留係数 $\mathrm{s}$ を $10^{-3}$ 程度, 地下水帯の広がりと流入経路の長さを約 $100 \mathrm{~m}$, 流 入経路の断面積を $1 \mathrm{~m}^{2}$ とすると, $\gamma$ は約 $10^{-5}$ となる。 時間雨量が数十 $\mathrm{mm}$ から $100 \mathrm{~mm}$ 程度であるとする と式(4)の $\Psi$ 関数における「H-h」の項の影響は極めて 少なく, 場合によっては省略も可能であると思われる。

つまり, $\Psi$ 関数を

$$
\Psi=\gamma \cdot \mathrm{p}
$$

と表現できる。

式 (5)の $\Psi$ 関数を用いた場合を, 変則 $\Psi$ 関数モデルと 呼ぶこととする。

変則 $\Psi$ 関数モデルでは $\gamma \times \varepsilon$ を一つの定数として扱 うことによって，未知数が 5 個となり，試行錯誤による 定数の決定がより容易になる。

変則 $\Psi$ 関数モデルでは $\gamma \times \varepsilon$ を改めて流域係数とよ び記号 $\beta$ で表すこととする。

変則 $\Psi$ 関数モデルにおける $\Psi$ 関数はつぎのようにな る。

$$
\begin{aligned}
& \Psi=\beta \sum_{\mathrm{n}=1}^{\infty} \alpha^{\mathrm{n}-1} \cdot \mathrm{R}_{-(\mathrm{T} 0+\Delta \mathrm{t} \cdot(\mathrm{n}-1))} \\
& \text { ここに, } \beta=\gamma \times \varepsilon
\end{aligned}
$$

\section{4. 解析方法}

二つのモデルの解析法を以下に述べる。両モデル共に 解析水位と観測水位との一致の程度を相関係数, 平均值 の比，分散の比によって判断する。それぞれが最も 1 に 近くなるように各定数を決定する。

\section{1 タンクモデル}

解析には平均貯留高を用いる収支計算法を用いた まず，各定数の值を推定して解析水位を求め, 観測水 位と比較しながら定数の值を変化させ, 観測水位と最も よく一致する定数を決定する。

\section{$4.2 \Psi$ 関数モデル}

以下に解析手順を述べる。

(1)手順 1: 水位低下係数 $\eta$ と水位基準点 $\mathrm{B}_{0}$ を推定す る。

最初に式 (2)の水位低下係数 $\eta$ を推定する。

図-6 は観測水位から求めた水位低下速度とすべり 面からの水位高の関係図の一例である。この水位低下 速度は無降雨時の水位データから算出しているが, 当 然降雨の影響が若干含まれている。被圧地下水帯の帯 水層厚 $\mathrm{B}$ を考慮して基準点 $\mathrm{B}_{0}$ を推定し, $\mathrm{h}=\mathrm{B}_{0}$ の点 を通る回帰直線の傾き $\mathrm{a}_{1}$ と全デー夕を包括する直線 の傾き $\mathrm{a}_{2}$ をもと，その間に求める比例定数 $\eta$ があ るとして值を推定する。 


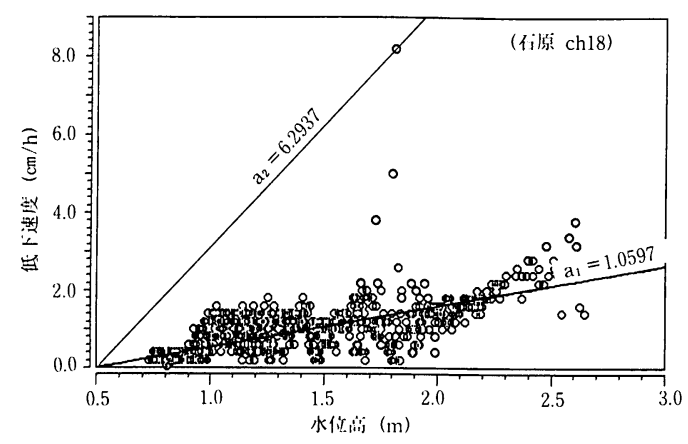

图-6 水位低下速度と水位高の関係図

(2)手順 2: 先行雨量効果残留率 $\alpha$ を推定する

観測水位の特徵より，1.0〜 0.0 間の值を推定する。 経験上，1日の残留率 $\alpha^{24}$ の值が 0.5 より大きいと 先行降雨の影響が大きく, 0.5 より小さいと先行降雨 の影響は少なくなる。

(3)手順 3: 流域係数 $\varepsilon$, 浸透係数 $\gamma$ を推定する。 式 (1)〜式 (4)の理論式より值を推定する。

(4)手順 4: 標高差 $\mathrm{H}$ を推定する。

すべり面深度や流域以内の標高差等を考虑して推定 する。

(5)手順 5: 初期遅延時間 $\mathrm{T}_{0}$ を与える。

経験上大多数の水位変動に対して, $\mathrm{T}_{0}=0$ として解 析可能である。降雨と水位のピーク間の時間差は十分 表現できる。水位の上昇開始時間が降雨より大きく遅 れる場合はその時間差を与える。

(6)手順 6: 解析水位を算出する。

初期水位 $h_{0}$ を与え, 式 (1) 式 (3)によって解析水位 をもとめて観測水位との一致の程度を調べる。各定数 を少しずつ変化させながら随時解析水位をもとめ, 定 数を決定する。

変則 $\Psi$ 関数モデルでは $\gamma \times \varepsilon$ を一つの定数として 解析し, 手順 4 が不要となる。

\section{5. 解析結果}

モデル適用の普遍性を見るために，各地の地すべり データから水位変動の特徵が大きく㒓うものを抽出して 解析を行った。

図ー7にタンクモデルによる解析水位と観測水位の対 比図を示す。これには水位変動パターンの違う観測水位 の一例をいくつか載せてある。図ー7(a)と(b)が比較的降 雨に敏感なパターン1。図ー7 の(c)と(d)が緩やかな変動を 示す, パターン 2 である。いずれも観測水位と解析水位 の一致の程度はよく, その変動の特徴をよく再現してい る。ピークの位置も合っており, 水位変動の大きさと時 間差, ピーク遅延時間をほほ正確に再現しているといえ る。 (a)

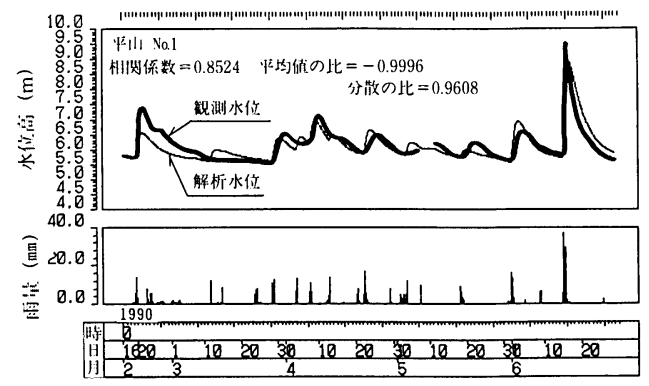

(b)

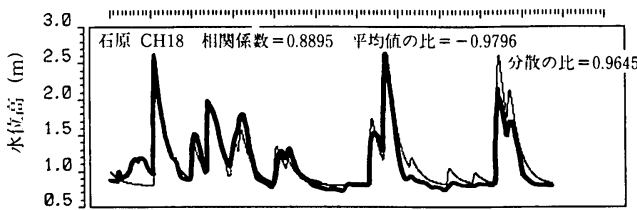

(c)

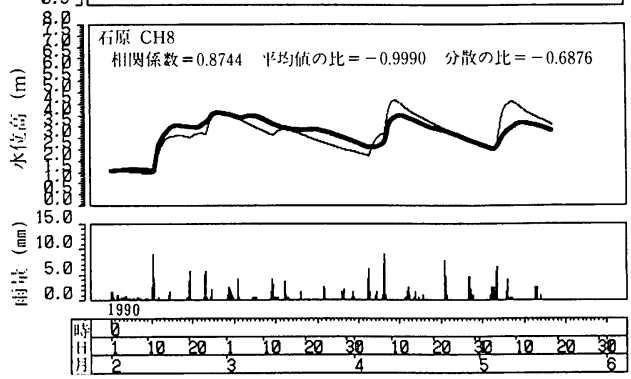

(d)

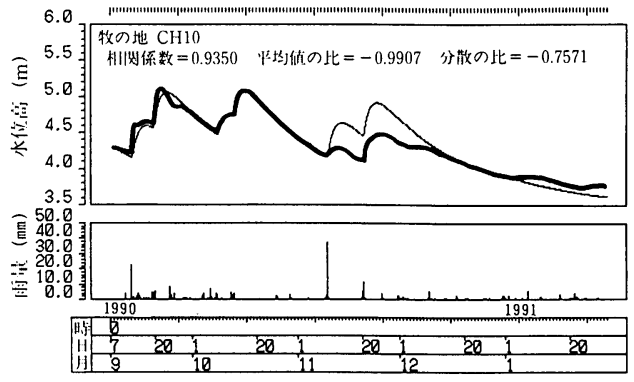

図ー7 タンクモデルによる解析水位と観測水位

表ー1に各地点のタンクモデルの定数を示す。

タンクは最上部タンクのみを自由地下水タンクとし, 一般的な地層の有効間隙率を貯留係数として与えた ${ }^{2)}$ 。

表より, 次のタンクへ流入する越流孔の越流係数 c は $\mathrm{c}=1.5 \times 10^{-3} \sim 8 \times 10^{-1}$ の範囲となっている。透水係数 $\mathrm{k}$ を $3.6 \times 10^{-2} \mathrm{~m} / \mathrm{hr}\left(=1 \times 10^{-3} \mathrm{~cm} / \mathrm{s}\right)$ 程度であると考える と妥当な值であると思われる。 $\mathrm{c}$ の值が透水係数 $\mathrm{k}$ より 大きい部分は, タンクを多く設定したため, タンク間の 距離やタンクの底面積が流入経路の断面樻より小さく なった影響と，傾向として，下のタンクほど貯留係数が 小さいことの影響であると思われる。

図-8に $\Psi$ 関数モデルによる解析水位と観測水位と の対比図の一例を示す。いずれの水位変動パターンもそ の変動の特徵がよく再現されており, 解析水位と観測水 位の一致の程度も高い。これも水位変動の大きさと時間 差をほほ正確に再現しているといえる。 
表ー1 タンクモデルの定数

\begin{tabular}{|c|c|c|c|c|c|c|}
\hline & 平山 No. 1 & 石原 $\quad \mathrm{CH} 18$ & 石原 $\mathrm{CH} 8$ & 牧の地 $\mathrm{CH} 10$ \\
\hline \multicolumn{3}{|c|}{ すべり面深度 GL-m } & 23.5 & 13.5 & 16.8 & 14.5 \\
\hline \multicolumn{3}{|c|}{ 集水係数 $\mathrm{a} / \mathrm{s}_{1}$} & 1000 & 150 & 150 & 200 \\
\hline \multirow{6}{*}{$\begin{array}{l}\text { 夕 } \\
\text { Y } \\
1\end{array}$} & 貯留係数 & $\mathrm{s}_{1}$ & 0.20 & 0.20 & 0.20 & 0.20 \\
\hline & 越流係数 & $\mathrm{c}_{11}$ & $8.0 \times 10^{-1}$ & $2.8 \times 10^{-1}$ & $3.5 \times 10^{-1}$ & $3.5 \times 10^{-1}$ \\
\hline & 越流高 & $Z_{11}$ & 5.00 & 0.78 & 0.68 & 0.65 \\
\hline & 越流係数 & $\mathrm{c}_{12}$ & $\overline{-}$ & $3.0 \times 10^{-3}$ & $2.0 \times 10^{-1}$ & $9.0 \times 10^{-1}$ \\
\hline & 越流高 & $\dot{z}_{12}$ & $\longrightarrow$ & 1.20 & 1.50 & 1.20 \\
\hline & 浸透係数 & $\mathrm{k}_{1}$ & $9.0 \times 10^{-2}$ & $1.2 \times 10^{-2}$ & $6.0 \times 10^{-2}$ & $4.0 \times 10^{-2}$ \\
\hline \multirow{6}{*}{$\begin{array}{l}\text { 夕 } \\
\text { Y } \\
\text { ク } \\
2\end{array}$} & 貯留係数 & $\mathrm{s}_{2}$ & - & $=$ & $=$ & $\bar{\square}$ \\
\hline & 越流係数 & $\mathrm{C}_{21}$ & $8.0 \times 10^{-1}$ & $2.8 \times 10^{-1}$ & $3.5 \times 10^{-1}$ & $3.5 \times 10^{-1}$ \\
\hline & 越流高 & $Z_{21}$ & 2.00 & 0.78 & 0.50 & 0.75 \\
\hline & 越流係数 & $\mathrm{c}_{22}$ & $\bar{C}$ & $3.0 \times 10^{-3}$ & $2.0 \times 10^{-5}$ & $5.0 \times 10^{-1}$ \\
\hline & 越流高 & $z_{22}$ & $\longrightarrow$ & 1.20 & 2.00 & 1.50 \\
\hline & 浸透係数 & $\mathrm{k}_{2}$ & $4.0 \times 10^{-2}$ & $1.6 \times 10^{-2}$ & $4.0 \times 10^{-2}$ & $4.0 \times 10^{-2}$ \\
\hline \multirow{6}{*}{$\begin{array}{l}\text { 夕 } \\
\text { Y } \\
3\end{array}$} & 貯留係数 & $\mathrm{S}_{3}$ & $\longrightarrow$ & $\overline{-}$ & $\longrightarrow$ & $\square$ \\
\hline & 越流係数 & $\mathrm{c}_{31}$ & $5.0 \times 10^{-1}$ & $2.8 \times 10^{-1}$ & $3.5 \times 10^{-1}$ & $3.5 \times 10^{-1}$ \\
\hline & 越流高 & $z_{31}$ & 2.40 & 0.78 & 0.50 & 0.75 \\
\hline & 越流係数 & $c_{32}$ & $\bar{\square}$ & $3.0 \times 10^{-3}$ & $2.0 \times 10^{-5}$ & $5.0 \times 10^{-1}$ \\
\hline & 越流高 & $Z_{32}$ & $\longrightarrow$ & 1.20 & 2.00 & 1.50 \\
\hline & 浸透係数 & $\mathrm{k}_{3}$ & $7.0 \times 10^{-1}$ & $5.0 \times 10^{-3}$ & $4.0 \times 10^{-2}$ & $4.0 \times 10^{-2}$ \\
\hline \multirow{6}{*}{$\begin{array}{l}\text { 夕 } \\
\text { Y } \\
\text { ク } \\
4\end{array}$} & 販留係数 & $\mathrm{s}_{4}$ & $\bar{L}$ & - & - & - \\
\hline & 越流係数 & $\mathrm{c}_{41}$ & $7.0 \times 10^{-3}$ & $2.8 \times 10^{-1}$ & $2.0 \times 10^{-2}$ & $2.0 \times 10^{-2}$ \\
\hline & 越流高 & $Z_{41}$ & 0.00 & 0.50 & 0.50 & 0.50 \\
\hline & 越流係数 & $\mathrm{C}_{42}$ & $8.0 \times 10^{-2}$ & $7.0 \times 10^{-1}$ & $1.5 \times 10^{-5}$ & $8.0 \times 10^{-1}$ \\
\hline & 越流高 & $Z_{42}$ & 6.50 & 0.55 & 2.00 & 1.10 \\
\hline & 漫透係数 & $\mathrm{k}_{4}$ & $4.5 \times 10^{-2}$ & $1.8 \times 10^{-3}$ & $3.0 \times 10^{-4}$ & $3.0 \times 10^{-4}$ \\
\hline \multirow{6}{*}{$\begin{array}{l}\text { 夕 } \\
\text { y } \\
5 \\
5\end{array}$} & 貯留係数 & $\mathrm{s}_{5}$ & $\longrightarrow$ & - & - & $\longrightarrow$ \\
\hline & 越流係数 & $\mathrm{c}_{51}$ & $1.0 \times 10^{-2}$ & $1.6 \times 10^{-2}$ & $1.5 \times 10^{-3}$ & $1.5 \times 10^{-3}$ \\
\hline & 越流高 & $Z_{51}$ & 5.80 & 0.80 & 1.00 & 3.50 \\
\hline & 越流係数 & $\mathrm{c}_{52}$ & - & $\square$ & $2.0 \times 10^{-2}$ & $\bar{\square}$ \\
\hline & 越流高 & $Z_{52}$ & $\bar{C}$ & $=$ & 4.00 & $\bar{C}$ \\
\hline & 漫透係数 & $\mathrm{k}_{5}$ & $2.0 \times 10^{-4}$ & $1.0 \times 10^{-5}$ & $1.0 \times 10^{-5}$ & $1.0 \times 10^{-5}$ \\
\hline \multicolumn{3}{|c|}{ 相関係数 } & 0.8524 & 0.8895 & 0.8744 & 0.9350 \\
\hline \multicolumn{3}{|c|}{ 注) 平均値の比 } & -0.9996 & -0.9796 & -0.9990 & -0.9907 \\
\hline \multicolumn{3}{|c|}{ 注）分散の比 } & 0.9608 & 0.9645 & -0.6876 & -0.7571 \\
\hline
\end{tabular}

注）解析水位の平均值および分散が観測水位のそれより大きい場合は偩の符号をつける。

この三つの例の場合, 変則 $\Psi$ 関数 モデルを用いることに問題はないと 思われる。いづれも水位変動の大き さと時間差をうまく再現できている。 表一 3 にモデル定数の表を示す。 表一 4 は夕ンクモデルと $\Psi$ 関数 モデルの定数を比較したものである。

表中の(1)がタンクモデルのタンク 1 からタンク 4 までの越流係数をか けあわせた值, (2)が $\Psi$ 関数モデルの 浸透係数 $\gamma$ である。その比からみて (2)の值が約 60 倍程度大きいが, ほぼ 同じ傾向の值を示していることがわ かる。(3のタンクモデルの係数の值 と, (4)の $\Psi$ 関数の流域係数 $\varepsilon$ と浸 透係数 $\gamma$ の積の值を比較しても，同 様にほほ同じ傾向の值であることが わかる。

二つのモデルの考え方が違うため, 同一の定数の值にはならないが，同 じような意味をもつ定数には共通し た傾向があるといえる。

\section{6. 考 察}

以上の結果より, タンクモデル， $\Psi$ 関数モデル共に地すべり地の地 下水位変動を十分に再現可能であり, 各定数の值が理論的な解釈の範囲に あることがわかる。

二つのモデル解析の特徴を比較し

表 -2 に各定数の值を示す。

先行雨量効果残留率 $\alpha$ は $0.980 \sim 0.990$ の值となって いる。 $\alpha^{24}$ の值で比較すると $0.616 〜 0.786$ で, 降雨の 24 時間後も 6 割以上の雨量効果が残留していることになり, 先行雨量の効果は比較的大きい。

図一8(a)の水位変動は視覚的には降雨に敏感な変動パ ターンに見えるが, 実際は先行降雨の影響が大きいこと がこの $\alpha$ からわかる。3 月後半や 4 月後半の水位変動が 少ないことをみてもその傾向がうかがえる。

この例では流域係数 $\gamma$ は $1 \times 10^{-5} \sim 1 \times 10^{-4}$, 水位低下係数 $\eta$ は $6.90 \times 10^{-4}$ 〜 $3.80 \times 10^{-2}$ の範囲となっている。水位低下係数 $\eta$ が水 位変動の特徵の違いをよく表現している。

図-9は $\Psi$ 関数モデルと同じ定数を変則 $\Psi$ 関数モデ ルに適用して求めた解析水位と観測水位の対比図である。 どれも水位変動の特徵をよく表現しており, 一致の度合 いも大きい。
てみる。

タンクモデルは根気よく解析を続けることで水位変動 特性の複雑で細かい違いを表現することが可能であると いう優れた利点をもっている。反面, モデル定数の数が 多く定数決定に要する試行錯誤の回数が多いこと。モデ ルの自由度が大きく, 同じ水位を再現する複数の定数の 組み合わせが考えられること。地すべり対策の立場から みた各定数のもつ意味が不鮮明であるなどの不利な点が ある。

$\Psi$ 関数モデルは単純な 2 層構造であり, 大きな水位変 動のピークは再現可能であるが, あまり細かい水位変動 特性の違いを表現するには不向きである。しかし，モデ ル定数の数も少なく, 定数決定に要する試行錯誤の回数 が少ないこと。一つ一つの定数が持つ地すべり対策上の 意味を明確にすることができるなどの利点がある。

$\Psi$ 関数モデルでは, 地すべり対策における各定数の持 つ意味を以下のようにまとめることができる。 

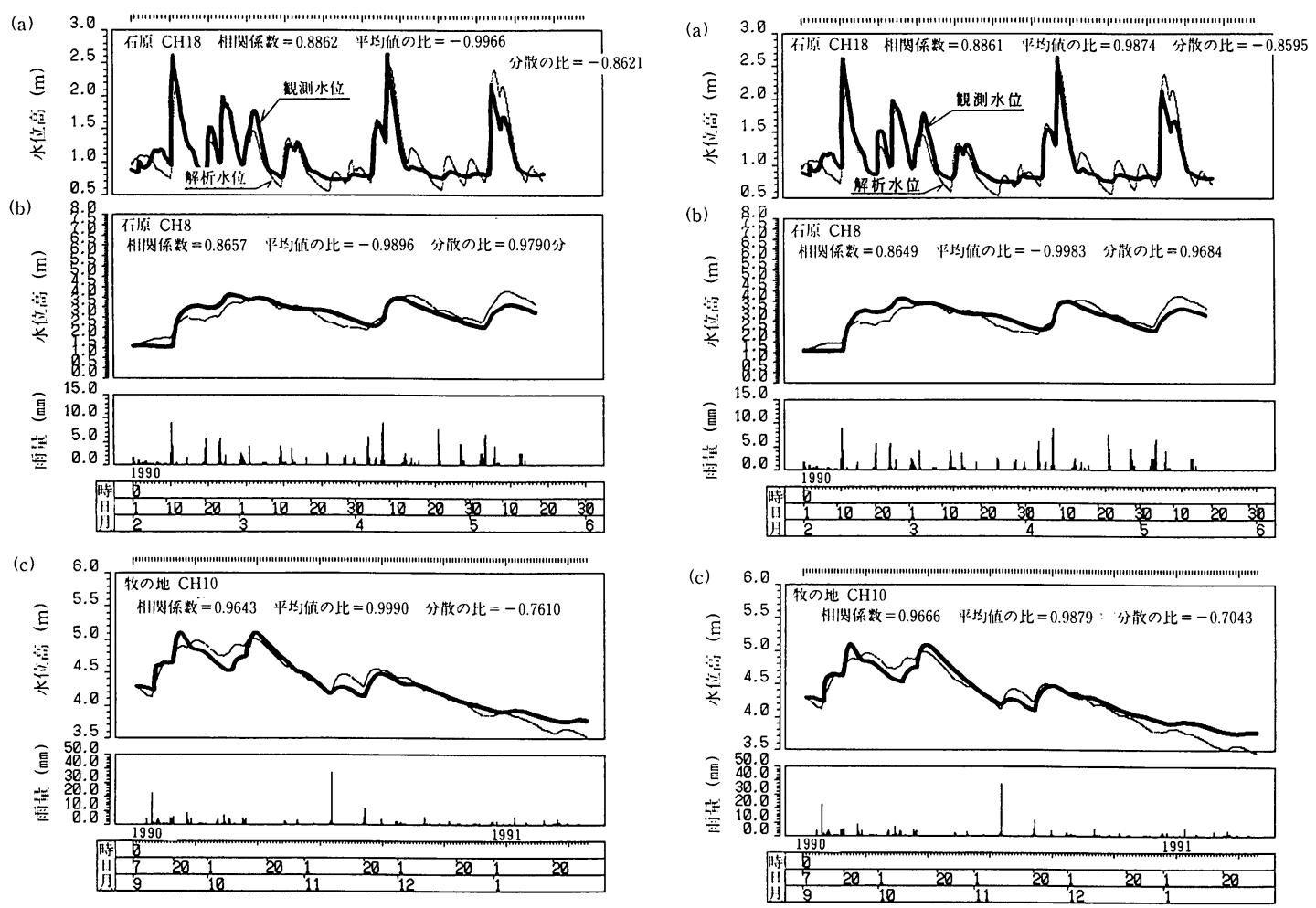

图ー8 $\Psi$ 関数モデルによる解析水位と観測水位

目ー9 変則 $\Psi$ 関数モデルによる解析水位と観測水位

表ー2 $\Psi$ 関数モデルの定数

\begin{tabular}{|c|c|c|c|c|c|}
\hline & 石原 ch 18 & 石原 $\operatorname{ch} 8$ & 牧の地 ch 10 \\
\hline \multicolumn{3}{|c|}{ すべり面深度 } & 13.5 & 16.8 & 14.5 \\
\hline \multirow{8}{*}{$\begin{array}{l}乇 \\
テ \\
\text { テ } \\
\text { ル } \\
\text { 定 } \\
\text { 数 }\end{array}$} & 先行雨㩆効果残 & 留率 & 0.9800 & 0.9900 & 0.9820 \\
\hline & 流域係数 & $\varepsilon$ & $2.00 \times 10^{4}$ & $2.00 \times 10^{4}$ & $2.10 \times 10^{4}$ \\
\hline & 浸透係数 & $\gamma\left[\mathrm{m}^{-2} / \mathrm{hr}\right]$ & $1.00 \times 10^{-4}$ & $2.00 \times 10^{-5}$ & $1.00 \times 10^{-5}$ \\
\hline & 水位低下係数 & $\eta[\mathrm{m} / \mathrm{hr} / \mathrm{m}]$ & $3.80 \times 10^{-2}$ & $3.00 \times 10^{-3}$ & $6.90 \times 10^{-4}$ \\
\hline & 水位基準点 & $\mathrm{B}_{0}[\mathrm{~m}]$ & 0.5 & 0.5 & 1.5 \\
\hline & 带水首標高差 & $\mathrm{H}[\mathrm{m}]$ & 8.0 & 8.0 & 10.0 \\
\hline & 初期遮延時間 & $\mathrm{T}_{0}[\mathrm{hr}]$ & 0.0 & 0.0 & 0.0 \\
\hline & 初期水位 & $\mathrm{h}_{0}[\mathrm{~m}]$ & 1.00 & 1.60 & 4.30 \\
\hline \multicolumn{3}{|c|}{ 相関係数 } & 0.8862 & 0.8657 & 0.9643 \\
\hline \multicolumn{3}{|c|}{ 平均值の比 } & -0.9966 & -0.9896 & 0.9990 \\
\hline \multicolumn{3}{|c|}{ 分散の比 } & -0.8621 & 0.9790 & -0.7610 \\
\hline
\end{tabular}

注）解析水位の平均値および分散が観測水位のそれより大きい場合は負の符号を付ける。

衰 -3 変則 $\Psi$ 関数モデルの定数

\begin{tabular}{|c|c|c|c|c|c|}
\hline & 石原 ch 18 & 石原 $\operatorname{ch} 8$ & 牧の地 $\operatorname{ch} 10$ \\
\hline \multicolumn{2}{|r|}{ すべり面深度 } & [GL-m] & 13.5 & 16.8 & 14.5 \\
\hline \multirow[b]{2}{*}{$\begin{array}{l}モ \\
=\end{array}$} & 先行雨当効果残 & 留率 & 0.9800 & 0.9900 & 0.9820 \\
\hline & 流域係数 & $\beta=\varepsilon \times \gamma$ & 2.00 & $4.00 \times 10^{-1}$ & $2.10 \times 10^{-1}$ \\
\hline $\begin{array}{l}\text { デ } \\
\text { ル }\end{array}$ & 水位低下係数 & $\eta[\mathrm{m} / \mathrm{hr} / \mathrm{m}]$ & $3.80 \times 10^{-2}$ & $3.00 \times 10^{-3}$ & $6.90 \times 10^{-4}$ \\
\hline \multirow{3}{*}{ 定 } & 水位基準点 & $\mathrm{B}_{0}[\mathrm{~m}]$ & 0.5 & 0.5 & 1.5 \\
\hline & 初期遅延時間 & $\mathrm{T}_{0}[\mathrm{hr}]$ & 0.0 & 0.0 & 0.0 \\
\hline & 初期水位 & $\mathrm{h}_{0}[\mathrm{~m}]$ & 1.00 & 1.60 & 4.30 \\
\hline \multicolumn{3}{|c|}{ 相関係数 } & 0.8861 & 0.8649 & 0.9666 \\
\hline \multicolumn{3}{|c|}{ 平均値の比 } & 0.9874 & -0.9983 & 0.9879 \\
\hline \multicolumn{3}{|c|}{ 分散の比 } & -0.8595 & 0.9684 & -0.7043 \\
\hline
\end{tabular}

注）解析水位の平均值および分散が観測水位のそれより大きい場合は負の符号を付ける。

\section{(1)先行雨量効果残留率 $\alpha$}

すべり面への地下水供給源で ある自由地下水帯の地下水の排 水性を表している。その近辺の 排水性をよくすることでこの值 は小さくなる。

(2)流域係数 $\varepsilon$

すべり面への地下水供給源で ある自由地下水帯の有効間隙率 と雨水の集まりやすさを反映し ており，地表からの雨水の供給 経路を絶つことで係数の值が小 さくなる。

(3)浸透係数 $\gamma$

自由地下水带からすべり面付 近の地下水帯への地下水の流入 経路の透水性と規模を反映して おり，流入経路を絶つことに よって係数の值は小さくなる。

また, $\varepsilon \times \gamma$ の值は降雨に対 する水位変動の大きさの程度を 表す。

(4)水位低下係数 $\eta$

すべり面付近の地下水帯の排 
表-4 モデル定数の比較

\begin{tabular}{|c|c|c|c|c|}
\hline & & 石原 $\quad \operatorname{ch} 18$ & 石原 $\operatorname{ch} 8$ & 牧の地 $\operatorname{ch~} 10$ \\
\hline (1) $C_{11} \cdot C_{21} \cdot C_{31} \cdot C_{41}$ & (タンクモデル) & $6.14 \times 10^{-3}$ & $8.58 \times 10^{-4}$ & $8.58 \times 10^{-4}$ \\
\hline (2) $\gamma$ & $(\Psi$ 関数モデル) & $1.00 \times 10^{-4}$ & $2.00 \times 10^{-5}$ & $1.00 \times 10^{-5}$ \\
\hline \multicolumn{2}{|c|}{ (2)/(1) } & 61.5 & 42.9 & 85.8 \\
\hline \multicolumn{2}{|c|}{ (3) $\mathrm{C}_{11} \cdot \mathrm{C}_{21} \cdot \mathrm{C}_{31} \cdot \mathrm{C}_{41} \cdot \mathrm{a} / \mathrm{s}_{1}($ タンクモデル) } & 0.922 & 0.129 & 0.172 \\
\hline \multirow[t]{2}{*}{ (4) $\beta=\varepsilon \cdot \gamma$} & $(\Psi$ 関数モデル) & 2.00 & 0.40 & 0.21 \\
\hline & & 2.2 & 3.1 & 1.2 \\
\hline
\end{tabular}

ぼ満たしている。地すべり地での 水位変動特性を把握していく上で, どちらも有効なモデルである。

小さい水位変動も含め限りなく 再現性のよい解析水位を追求する のであれば自由度の大きいタンク モデルを用い, 小さな水位変動は 重視せず，モデル定数の特性値と

水性を表し, 集水ボーリング等で排水性をよくする ことで係数の值が大きくなる。

ここで, 第 3 章で述べた地すべり地での水位変動モデ ルに求められる 7 つ条件に基づいて二つのモデルを評 価してみる。

(1)水位変動の大きさを予測できるか:

どのモデルも変動パターンの違う水位変動の大き さを十分に再現している。

すでに決定されたモデル定数があれば，降雨が記 録された時点で, 水位がどこまで上昇するのか予測 できる。

(2)時間差を予測できるか:

どちらのモデルも予測可能である。

牧の地 $\mathrm{CH} 10$ の観測水位のピーク遅延時間 $\mathrm{T}_{\mathrm{p}}$ は約 36 時間〜 120 時間と大きな開きがあるが，どの モデルもそのほとんどのピークの時間差を再現して いる。

ピーク遅延時間はその地点固有の值ではなくその ときの条件によって変化するのであって,この二つ のモデルは非常に有効である。

すでに決定された各地点のモデル定数があれば, 豪雨が記録された時点で, その何時間後に水位がど の位置にあるかを予想できる。

(3)理論的な裏付けがあるか:

どちらも裏付けがある。

(4)モデル定数の決定が容易であるか:

モデル定数の数から， $\Psi$ 関数が有利である。

(5)計算方法が簡単・明瞭であるか:

どちらも簡単・明瞭である。

(6)モデル定数が水位変動の特性を言い表す特性值とな り得るか:

$\Psi$ 関数のモデル定数の方がより端的に水位変動 の特性を反映している。

(7)一つの解析の所要時間が短時間であるか:

どちらも 1 時間間隔, 約 3000 時間分のデー夕解析 の所要時間が, 16 ビットパソコンで 2 ～3 分程度で あり，十分実用的である。

どちらのモデルも理論的, 概念的に水位変動機構をわ かりやすく説明しており, モデルに求められる条件をほ
しての意義を重視する場合は $\Psi$ 関数を用いるという使 い分けも考えられる。

しかし, 本研究の結果では, 地すべり地における水位 変動モデルとしての全体的な評価においては $\Psi$ 関数モ デルが優位であるといえる。

$\Psi$ 関数モデルでは基本的にすべり面付近の地下水帯 を被圧地下水帯または有圧水帯と仮定しているが，自由 地下水带であっても, いくつかの定数の理論的意味が少 し変化するだけで, 十分解析可能であると思われる。こ のことはこれからの研究によって明らかになってゆくで あろう。

本研究では本文で取り上げた地区以外に, 長崎県石倉 木場地すべり, 長崎県藏田・小川内地すべり, 大分県山 内地すべり等の水位デー夕に対する解析も行ったが, ど れも良い結果を得ている。

また，筆者はこれまでの数年間の水位変動解析で, こ こでいう変則 $\Psi$ 関数モデルを多用してきたが, どの地す べり地においてもおおむね満足できる解析結果を得てい る $^{7) 8) 9)}$ 。

\section{7.まとめ}

本研究の成果を以下にまとめる。

(1)地すべり地の水位変動特性を表現するタンクモデル と $\Psi$ 関数モデル, 二つの理論的なモデルを構築し た。

(2)地すべり地における水位変動のモデル解析の意義を 整理した。

(3)二つのモデル共に，パターンの異なった水位変動に おいて降雨に対する水位変動の大きさと時間的なず れを十分に表現することができた。

(4) $\Psi$ 関数モデルのモデル定数が, 地すべり対策に利用 可能なその地点の水位変動の特性值となることがわ かった。

(5)二つのモデル共に地すべり地での水位変動解析モデ ルとして有効であるが, 現時点では $\Psi$ 関数モデルが 優位であることがわかった。

(6)モデル適用の普遍性の検証は, 複数の地すべり地に においてモデルの適合性をみることと, 大きく違う 水位変動パターンに対する適合性をみることで行っ 
たが，その範囲において普遍性が確認された。

今後, 研究を重ねることで各モデル定数と地質条件等

の関係も明らかにしてゆく予定である。

このタンクモデルおよび $\Psi$ 関数モデルが今後の地す ベり対策に少しでも役立てば幸いである。

なお，この論文作成に当たって助言をいただいた国土 防災技術株式会社 申潤植博士と佐賀大学理工学部 岸 原信義教授，岩尾雄四郎教授，ならびに貴重なデー夕を 提供いただいた長崎県北振興局および岐阜県高山土木事 務所に対し，心より感謝の意を表します。

\section{参考文献}

1 ）申 潤植: 地すべり工学，pp. 71，山海堂，1989

2 ) 申 潤植: 地すべり工学, pp. 106, 山海堂, 1989
3 ) 粟津清蔵: 水理学, pp. 173 191, オーム社, 1980

4 ）東京天文台: 理科年表, pp. 物 25, 丸善, 1973

5 ) 申 潤植: 地すべり工学, pp. 181〜183, 山海堂, 1989

6 ）佐藤勝夫: 洪水流出計算法, pp. 205〜233, 山海堂, 1982

7 ）榎田充哉: 地すべり自動観測システムの応用への展望一 その 1 降雨と地下水位変動の解析, 第 28 回地すべり学 会研究発表講演集, pp. 124〜 127, 1989

8 ）榎田充哉・申 潤植: 地すべり地における降雨と地下水 位変動パターンの解析, 第 29 回地すべり学会研究発表講 演集, 1990

9 ）榎田充哉 - 申 潤植: Prospect for the Application of Automatic Observation System to the Landslide Engineering (1)-On the Model of Rainfall vs. Ground Water Level Fluctuation-, 日中地すべりシンポ ジューム発表論文集, pp. 105〜 108，1989

10）水収支研究グループ: 地下水盆の管理一理論と実際一, pp. 77〜224, 東海大学出版会, 1976

11) 戸川隼人: 数値解析とシミュレーション, pp. 15〜 73, 共 立出版，1977

（原稿受理日 平成 4 年 4 月 2 日）

\section{「地すべり自動観測システム技術連絡会」が発足}

平成 4 年 1 月, 地すべり自動観測技術の向上と普及を促進することを目的として「地すべり自動観測システム技術連 絡会」が発足致しました。

同会は，建設省技術評価規定により技術認定を受けた 17 社で構成され，会長には(侏)日くの寺川俊浩氏，副会長に応 用地質(侏)の松原幹夫氏が就任されました。 5 月 28 日には第 1 回総会が開催され, 今後の活動方針として機器仕様の統一 と標準歩掛の検討を行うことが決定されました。

[会 員]

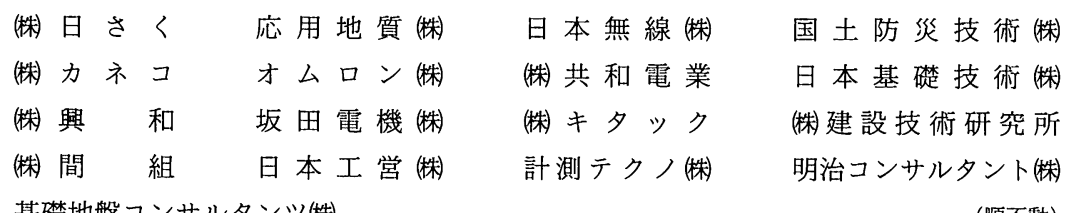

基礎地盤コンサルタンツ(侏)

(順不動)

[連絡先］１１02 東京都千代田区麭町 2-5（ニッキビル）

日本工営保) システム営業室内

地すべり自動観測システム技術連絡会事務局

TEL. 03-3238-8105 Fax. 03-3263-3301 
千葉県嶺丘隆起帯縁辺部の粘質土地すべりの発生機構と対策

「地すべり」Vol. 29, No. 2（通算第 110 号）pp. 1〜11，1992 年（平成 4 年）9月

守随 治雄

長者地すべり地における地すべり斜面の変遷過程

「地すべり」Vol. 29, No. 2（通算第 110 号）pp. 12 19, 1992 年（平成 4 年）9 月

檜垣 大助

高知県長者地すべり地において，地質ボーリング資料から地すべり斜面の変遷過程を考察した。

当地すべり地は少なくとも 1,000 年以上前からの順次移動ブロックを拡大する後退性地すべりとして形成され

てきた。現在の地すべりの活動も過去の地すべり斜面変遷過程とよく調和している。

降雨, 地下水変動による土地電位の挙動

「地すべり」Vol. 29, No. 2（通算第 110 号）pp. 20〜27, 1992 年（平成 4 年）9月

伊藤 芳朗, 南雲 政博

新潟県平丸の地すべり観測システムにおいて, 観測された土地電位の変化について, 次の 3 タイプについて詳 述した。(1)降雨によって発生する中間流に伴う流動電位, 降雨電位効果。(2)地下水流動による流動電位, 地下水 電位効果。(3)断続降雨と地下水位変動に伴う流動電位, 複合電位効果。土地電位の連続観測は, 降雨による表面 流出，中間流，漫透，地下水涵養，地下水流動などの考察に，有力な情報を提供することを示した。

地すべり地における水位変動のモデル解析

「地すべり」Vol. 29, No. 2（通算第 110 号）pp. 28〜38, 1992 年（平成 4 年）9月

榎田 充哉

地すべり滑動にすべり面の間隙水圧が関与していることは周知の事実であるが，本研究では地すべり地の水位 変動をモデル化し，モデル化することの意義とモデルの有効性について検討を行った。

破砕帯地すべりにおける地下水位の挙動特性

「地すべり」Vol. 29, No. 2 (通算第 110 号) pp. 39〜45, 1992 年（平成 4 年） 9 月

近藤 観慈, 吉松 弘行, 吉田 克美

河川流出解析にしばしば用いられる合理式の考え方を基本にし，地下水位の季節的な変動值が明かな場合に， 降雨による地下水位変化が予測できる地下水位上昇モデルを検討した。このモデルの妥当性を検討するため, 谷 の内地すべりと口坂本地すべりを対象に解析を実施し，このモデルの特徴を確認した。このモデルが既往のデー 夕から同定できれば，降雨による地すべりの地下水位等の挙動特性を明らかにすることができることを示した。 